O. А. Колмакова. Рассказ А. П. Платонова «Река Потудань»: интерпретация в свете теории 3. Фрейда о бессознательном

Научная статья

УДК 821.161 .1

DOI: $10.18101 / 2686-7095-2021-1-55-60$

\title{
РАССКАЗ А. П. ПЛАТОНОВА «РЕКА ПОТУДАНЬ»: ИНТЕРПРЕТАЦИЯ В СВЕТЕ ТЕОРИИ З. ФРЕЙДА О БЕССОЗНАТЕЛЬНОМ
}

\author{
(c) Колмакова Оксана Анатольевна \\ доктор филологических наук, доцент, \\ Бурятский государственный университет имени Доржи Банзарова \\ Россия, 670000, г. Улан-Удэ, ул. Ранжурова, 6 \\ post-oxygen@mail.ru
}

\begin{abstract}
Аннотация. Художественный мир произведений Андрея Платонова сложен и уникален и во многом сформирован личным опытом писателя - инженера, художника и философа. Три ипостаси автора позволяют определить путь интерпретации его программного рассказа «Река Потудань». Предложенный в статье анализ проблемного поля рассказа раскрывает символическое содержание ключевых образов произведения с позиций теории 3. Фрейда. Образы Никиты Фирсова, Любы Кузнецовой, образсимвол реки Потудань рассмотрены как «коды» основных элементов, выделенных Фрейдом в структуре сознания. Обращение к психоанализу позволяет выявить глубинное философское содержание указанных образов, каждый из которых может быть соотнесен с категориями учения 3. Фрейда о бессознательном - «Я», «Сверх-Я», «Оно».
\end{abstract}

Ключевые слова: А. П. Платонов; «Река Потудань»; бессознательное; образ-символ; мотив; сюжет.

\section{Для цитирования}

Колмакова О. А. Рассказ А. П. Платонова «Река Потудань»: интерпретация в свете теории 3. Фрейда о бессознательном // Вестник Бурятского государственного университета. Филология. 2021. Вып. 1. С. 55-60.

Несмотря на требование сугубо материалистического видения мира, декларируемое официальной идеологией, А. П. Платонов продолжал следовать русской классической традиции, изображая метафизические горизонты человеческого существования. Значимость для художника стратегии философского обобщения Платонов отмечал в своих записных книжках: «Все искусство заключено в том, чтобы выйти за пределы собственной головы» [5, с. 320].

Исследователи творчества А. П. Платонова не раз писали о знакомстве писателя с передовой философской мыслью конца XIX — первой половины XX в. В. Чалмаев называет ряд имен, чьи философские концепции в той или иной степени отразились в «самодельном философствовании» писателя: А. Богданов, О. Шпенглер, В. Розанов, Н. Федоров, В. Вернадский [10]. Попытаемся пополнить этот ряд еще одним представителем философской науки, выявив связь художественного мира рассказа «Река Потудань» с учением 3. Фрейда о бессознательном как элементе структуры сознания.

На наш взгляд, структурный анализ произведений Платонова, вскрывающий механизмы «сделанности» текста, отвечает творческим стратегиям писателя- 
художника и одновременно талантливого инженера-изобретателя. Кроме того, подобный подход демонстрирует взаимосвязи разных уровней поэтики и проблематики произведения. Несмотря на некоторую тенденциозность, односторонность структурного анализа, имеются и несомненные достоинства его применения, в частности возможность выявить принципы организации художественного пространства текста, представить систему образов или различные уровни развития сюжета.

Традиционное платоноведение предлагает следующие варианты анализа сюжета «Реки Потудани». В. Чалмаев пишет об этом тексте как о «поэме воспитания чувств», изображающей «трудный путь одного человека к другому... жизнь влюбленных, идущих к действительному единению не через упрощение, огрубление, а через множество существенных для них сложностей» [10, с. 411]. Трудно согласиться с этой интерпретацией, поскольку единение людей осуществляется не на телесном, а на духовном уровне. Проблема запрета физической любви для Никиты видится читателю более сложной и глубокой. Тем более что в приведенном толковании никак не объясняется символика образа Потудани. Вынесенный в заглавие, этот образ, очевидно, имеет значительную смысловую нагрузку.

С. Бочаров вписывает рассказ в контекст платоновского творчества и называет его «антиутопией», ставшей результатом развития утопической идеи раннего Платонова о слиянии духовной, эмоциональной и физической силы в человеке: «Это новая <...> история “слабого сердца”, для которого счастье оказалось “тяжким трудом"» [1, с. 266]. Безусловно, антиутопия - один из ведущих жанров А. Платонова, а зрелое творчество писателя представляет собой диалог с ранней публицистикой, декларирующей коллективизм и «царство сознания». Однако основная коллизия рассказа, представленная исследователем как «мягкая любовь платоновского человека - жестокая жалкая сила», выглядит слишком отвлеченно и также не проясняет заглавия.

Целесообразность традиционного анализа рассказа может быть оспорена еще и потому, что он написан в русле модернистской эстетики, к которой тяготеет все творчество писателя. В статье «Об искусстве» (1919) А. Платонов демонстрирует осмысление искусства, говоря о нем как об «идеале своего я, осуществленном в безграничном хаосе» того, что он называет «миром» [10, с. 103]. На наш взгляд, адекватность интерпретации рассказа обеспечит методология, основывающаяся на выделении бинарных оппозиций.

В своей интерпретации рассказа «Река Потудань» мы будем опираться на идею автобиографизма прозы Платонова, о чем справедливо писал Л. Шубин [8]. В рассказе автобиографических черт более чем достаточно. Прежде всего Потудань - реальная река в Воронежской области, родины писателя. Имя героя Никита Фирсов - связано с именем деда Платонова, которого звали Фирс. Портрет Никиты напоминает одного литературного героя - Алешу Карамазова, что отсылает к Ф. М. Достоевскому, на которого, по воспоминаниям Г. 3. ЛитвинаМолотова, был поразительно похож молодой Платонов [8]. Автобиографические аллюзии играют в контексте рассказа роль лейтмотивов и задают тему родины, сквозную в творчестве Платонова. Таким образом, в центре художественного пространства рассказа оказывается главный герой, открывающий очередную 
О. А. Колмакова. Рассказ А. П. Платонова «Река Потудань»: интерпретация в свете теории 3. Фрейда о бессознательном

грань художественного мира писателя. Эту мысль подтверждает и анализ нарративной техники, тяготеющей к несобственно-авторскому повествованию.

Обратимся к символике названия рассказа. Рассматривая «взаимоотношения» текста и его заглавия, Н. Веселова и Ю. Орлицкий говорят о таком поэтическом приеме, когда название «открывает текст, являясь отправной точкой его развертывания <...> Его отделение от текста невозможно без разрушения самой текстовой структуры <..> Текст в отрыве от заголовка может быть попросту непонятен» [2, с. 117]. К нашему анализу «Реки Потудани» это наблюдение имеет прямое отношение.

Раскрывая образ-символ реки через эпизоды описания воды в рассказе, выстраиваем ряд: «река - ручей - родник», который закономерно продолжаем словом «родина». Крайние члены цепочки формируют центральную оппозицию рассказа: «река - Родина». Обычное представление о родине как о земле (а не о воде) у Никиты преломляется через образ реки: «Река Потудань тоже всю зиму таилась подо льдом, и озимые хлеба дремали под снегом» [7, с. 352-353]. Еще одно важное наблюдение за образом Потудани в тексте связано с тем, что Никита воспринимает ее как живое существо: зимой он ходит по льду «уснувщей реки» и размышляет, насколько «счастлива» Потудань, которая «таится подо льдом». Итак, мы можем выделить в тексте три оппозиции: «Никита - родина», «Никита - река Потудань», «река Потудань — родина». Основная коллизия сюжетнокомпозиционного уровня поэтики рассказа, любовь героев, вносит в наш анализ четвертую ключевую оппозицию «Никита - Люба». Следовательно, цепочка основных образов рассказа будет выглядеть так: «Река Потудань - Родина Никита - Люба». При этом написание полного имени героини - Любовь кардинально меняет смысл любовной коллизии: «Река Потудань - Родина - Никита - Любовь».

Последняя цепочка наглядно раскрывает основную тему рассказа - любовь к родине. Эта тема заявлена в названии еще одного произведения А. Платонова позднего периода его творчества - рассказа «Любовь к родине, или Путешествие воробья». Эти тексты следуют друг за другом в книге «Вся жизнь», составленной женой писателя М. А. Платоновой, что говорит в пользу общности их проблематики. Невозможность для Никиты физической близости с Любой объясняется тем, что в «живой Любе» для героя персонифицирован идеальный образ родины, которая, как видно из наших рассуждений, воспринимается Никитой через «жизнь» Потудани.

Перелом в отношении Никиты к Любе наступает после рокового известия о том, что она пыталась утопиться в Потудани. Для Никиты происходит расподобление двух дорогих для него образов - Любы Кузнецовой и родины. И все же нельзя уменьшать значение любовной коллизии в рассказе. Тема любви раскрыта в нем, с одной стороны, вполне традиционно для русской литературы. Концептуальное содержание этой темы выявляется из анализа соответствующих эпизодов. Для Никиты любовь - это прежде всего близость именно на духовном уровне, когда единственной мыслью перед лицом смерти становится мысль о любимом человеке. Любви обоих героев также присущ мотив жертвенности.

Тем не менее в поведении Никиты много «странного», что можно объяснить знакомством Платонова с фрейдовской теорией психоанализа. Литературоведы 
отмечали, что уже к середине 1920-х гг. «в среде российских писателей усиливается интерес к бергсонианству, интуитивным, подсознательным проблемам бытия человека» [6, с. 236]. В пользу важности для Платонова теории 3. Фрейда говорит сон Никиты, ведь ученый активно использовал в качестве иллюстративного материала своей теории сновидения пациентов: «Ему приснился страшный сон, что его душит своею горячею шерстью маленькое, упитанное животное <...> стараясь пробраться цепкими лапками в самую середину его души, чтобы сжечь его дыхание» [7, с. 338].

Взгляд сквозь призму философии Фрейда обнаруживает скрытые мотивы иррационального глиняного творчества Никиты. Он лепил «мертвые вымыслы в виде горы с выросшей из нее головой животного или корневища дерева, причем корень был как бы обыкновенный, но столь запутанный, впившийся одним своим отростком в другой, грызущий и мучающий сам себя, что от долгого наблюдения этого корня хотелось спать» [7, с. 357-358]. По Фрейду, в художественном творчестве происходит сублимация - переключение природного влечения либидо с культурно неприемлемых целей (для героя это физическая любовь к родине) на иную цель, нравственно одобряемую и общественно полезную (создание духовных ценностей).

Образ Потудани символизирует ключевое понятие психоанализа - бессознательное. Немаловажно то, что Фрейд раскрывал сущность категории «бессознательного», реифицируя его в образ воды: «Там, где было Оно, должно стать Я. Это примерно такая же культурная работа, как осушение Зейдер-Зе» [9, с. 349]. «Сверх-Я» - это общественные нормы брака, которые в совокупности с «Внешним миром» требуют от героя «умения наслаждаться», чего он не может себе позволить. Чрезмерное давление «Сверх-Я» и «Внешнего мира» на «Оно» усиливает мощь последнего. Потудань влечет к себе Никиту: он заворожен ее водами и едва не топится. Сам Никита - воплощение третьей ипостаси сознания: «Я». Психическое потрясение, пережитое героем от известия о попытке самоубийства Любы, возвращает в сознание Никиты рациональное начало, которое стало постепенно затухать в нем: «Отвыкнув сначала говорить, он и думать, вспоминать стал меньше» [7, с. 361]. Фрейд утверждал, что «Я» постоянно находится под давлением трех тиранов: «внешнего мира», «Сверх-Я» и «Оно» [9, с. 348]. Следовательно, каждый образ рассказа имеет психоаналитическую подоснову: «Никита - Я», «Река Потудань - Оно», «Родина - Сверх-Я», «Люба - Внешний мир».

В мире произведений Платонова категория бессознательного играет важную роль. Платоновские герои постоянно испытывают на себе влияние трансцендентных инфернальных сущностей из сферы бессознательного, которые не в силах подавить цензура «Сверх-Я». Отсюда гротескные мотивы («обжитые» гробы или смерть «из любопытства» Саши Дванова) и сюрреалистические образы в романе «Чевенгур» («батрак-медведь» или «красный рыцарь» Копенкин).

Автобиографический дискурс и «детские ошибки в языке» (С. Г. Бочаров) также обосновываются некоторыми положениями теории Фрейда. Автобиографизм может быть связан с тем, что овладение психоанализом происходит «прежде всего на самом себе, при изучении своей личности» [9, с 10], а «детский стиль» - свидетельство неотрефлексированного повествования на бессознатель- 
О. А. Колмакова. Рассказ А. П. Платонова «Река Потудань»: интерпретация в свете теории 3. Фрейда о бессознательном

ном уровне, так как «бессознательное душевной жизни и есть инфантильное» [9, c. 133]. Данные факты свидетельствуют о правомерности использования теории Фрейда в интерпретации произведений А. Платонова.

Применение структурного анализа позволило выявить взаимосвязь поэтики и проблематики в рассказе А. Платонова «Река Потудань». На первом этапе анализа в каждом образе текста выявлено сверхзначимое символическое расширение, превращающее рассказ из «гимна любви» в притчу. На следующем этапе раскрыто влияние на поэтику произведения психоанализа Фрейда, основные идеи которого могут стать ключом к поэтическому миру А. П. Платонова.

\section{Литература}

1. Бочаров С. Г. О художественных мирах. Москва: Советская Россия, 1985. 296 с. Текст: непосредственный.

2. Веселова Н., Орлицкий Ю. Заметки о заглавии (в русской поэзии 1980-1990 годов) // Арион. 1998. № 1. С. 114-120. Текст: непосредственный.

3. Дужина Н. И. Андрей Платонов: поход на тайны // Литературное обозрение. 1998. № 2. С. 47-54. Текст: непосредственный.

4. Корниенко Н. В. Наследие Платонова - испытание для филологической науки // Известия РАН. Сер. Лит. и яз. 1999. № 5-6. С. 10-25. Текст: непосредственный.

5. Корниенко Н. Повествовательная стратегия Платонова в свете текстологии // «Страна философов» Андрея Платонова: проблемы творчества. Вып. 2. Москва: Наследие, 1995. С. 312-335. Текст: непосредственный.

6. Михаил Зощенко. Материалы к творческой биографии. Санкт-Петербург: Наука, 1997. 240 с. Текст: непосредственный.

7. Платонов А. П. Вся жизнь. Москва: Патриот, 1991. 364 с. Текст: непосредственный.

8. Творчество Андрея Платонова: исследования и материалы. Библиография. СанктПетербург: Наука, 1995. 360 с. Текст: непосредственный.

9. Фрейд 3. Введение в психоанализ: лекции. Москва: Наука, 1989. 456 с. Текст: непосредственный.

10. Чалмаев В. Андрей Платонов (К сокровенному человеку). Москва: Советский писатель, 1989. 446 с. Текст: непосредственный.

Статья поступила в редакцию 24.11.2020; одобрена после рецензирования 28.01.2021; принята к публикации 25.03.2021.

«THE RIVER POTUDAN» BY ANDREI PLATONOV:

\section{INTERPRETATION IN THE LIGHT OF FREUD'S THEORY OF THE UNCONSCIOUS}

Oksana A. Kolmakova

Dr. Sci. (Phil.), A/Prof.,

Dorzhi Banzarov Buryat State University

6, Ranzhurova St., Ulan-Ude 670000, Russia

post-oxygen@mail.ru

Abstract. The artistic world of Andrei Platonov's works is complex and unique and is largely shaped by the personal experience of the writer, who was an engineer, artist and philosopher. These three Platonov's hypostases determined the way of interpretation of his "The River Potudan". The analysis of the story's problematic field proposed in the article reveals the symbolic content of the key images from the positions of Sigmund Freud's theory. The 
images-symbols of Nikita Firsov, Lyuba Kuznetsova, and the River Potudan are reviewed as the main elements "codes" identified by Freud in the structure of consciousness. Reference to psychoanalysis helps reveal the deep philosophical content of these images, each of them can be correlated with one of the main categories of Freud's studies on the unconscious ("Id", "ego" and "super-ego").

Keywords: Andrei Platonov; "The River Potudan"; unconscious; image; motif; plot.

\section{For citation}

Kolmakova O. A. «The River Potudan» by Andrei Platonov: Interpretation in the Light of Freud's Theory of the Unconscious. Bulletin of Buryat State University. Philology. 2021; 1 : 55-60 (In Russ.).

The article was submitted 24.11.2020; approved after reviewing 28.01.2021; accepted for publication 25.03.2021. 